\title{
Ekstraksi Na-Alginat dari Rumput Laut Padina sp. Menggunakan Konsentrasi Kalium Hidroksida yang Berbeda
}

\author{
Elza Septiani ${ }^{1}$, Ginanjar Pratama ${ }^{1}$, Raja Marwita Sari Putri ${ }^{1}$ \\ 1Jurusan Teknologi Hasil Perikanan Fakultas IImu Kelautan dan Perikanan, \\ Universitas Maritim Raja Ali Haji, Tanjung Pinang \\ Email : elzaseptianii14@gmail.com
}

\begin{abstract}
The objective of this study was to obtain the best sodium alginate extract from Padina sp. with different potassium hydroxide concentration. Padina sp. was collected in coastal Senggarang, Tanjungpinang, Riau Islands Province. The raw material of Padina sp. was extraction by potassium hydroxide with different concentration $(0.6 \%, 0.8 \%, 1 \%)$. We analyzed content of moisture, ash, yield, viscosity and $\mathrm{pH}$. The best results obtained in the treatment with a solution of $\mathrm{KOH}$ concentration $0,8 \%$ with content of moisture $10,87 \%$, ash $31,24 \%$, yield $17,82 \%$, viscosity $275,50 \mathrm{cP}$ and $\mathrm{pH} 8,21$.
\end{abstract}

Keywords : Padina sp., phaeophyceae, potassium hydroxide, seaweed, sodium alginate.

\begin{abstract}
Abstrak
Tujuan dari penelitian ini adalah untuk mendapatkan ekstrak natrium alginat terbaik dari rumput laut jenis Padina sp. dengan perlakuan konsentrasi kalium hidroksida yang berbeda. Padina sp. pada penelitian ini berasal dari Perairan Senggarang, Kota Tanjungpinang. Tahapan pada penelitian ini meliputi preparasi bahan baku, ekstraksi natrium alginat dengan perlakuan konsentrasi kalium hidroksida yang berbeda sebesar $0,6 \%, 0,8 \%$, dan $1 \%$, selanjutnya analisis kandungan natrium alginat yang meliputi kadar air, kadar abu, rendemen, viskositas dan $\mathrm{pH}$. Hasil perlakuan terbaik terdapat pada konsentrasi $\mathrm{KOH} 0,8 \%$ yaitu dengan nilai kadar air 10,87\%, kadar abu $31,24 \%$, rendemen $17,82 \%$, viskositas 275,50 cP dan $\mathrm{pH} 8,21$.
\end{abstract}

Kata kunci : Padina sp., phaeophyceae, kalium hidroksida, rumput laut, natrium alginat.

\section{Pendahuluan}

Potensi produksi rumput laut cokelat cukup melimpah, sampai saat ini pemanfaatannya masih sangat kurang, bahkan di Kepulauan Riau belum dimanfaatkan dengan maksimal. Jenis rumput laut yang digunakan dalam penelitian adalah Padina sp. upaya memproduksi alginat telah dilakukan melalui penelitian-penelitian sebelumnya yaitu jenis Padina sp. (Rasyid, 2007; Mushollaeni et al., 2011), Turbinaria sp. (Mushollaeni et al., 2011; Wibowo et al., 2013), Sargassum sp. (Junianto, 2006; Mushollaeni et al., 2011; Subaryono et al., 2010; Anwar et al., 2013; Mirza et al., 2013) tetapi yang menjadi kendala sampai saat ini adalah kondisi optimal yang diperlukan selama proses ekstraksi. Rekayasa proses ekstraksi dari rumput laut jenis Padina sp. perlu dilakukan agar menghasilkan Natrium alginat dengan kualitas yang baik. Penelitian ini memberi perlakuan konsentrasi kalium hidroksida yang berbeda yang diharapkan mampu untuk meningkatkan kualitas natrium alginat.

Produksi rumput laut di Indonesia saat ini telah mengalami peningkatan yang cukup signifikan. Produksi rumput laut pada tahun 2014 mencapai 10,2 juta ton atau meningkat lebih dari tiga kali lipat (KKP, 2015). Indonesia masih mengimpor produk alginat 1.100 ton/tahun (Kadi, 2005).

Alginat terdapat secara alami dalam berbagai jenis rumput laut coklat. Alginat merupakan garam dari asam alginat, yang tersusun oleh dua unit monomerik, yaitu $\beta-D$ mannuronic acid dan $\alpha$-L-guluronic acid. (Kendal et al., 2004; Viswanathan dan Nallamuthu, 2014). Alginat merupakan jenis polisakarida yang terdapat dalam dinding sel rumput laut coklat dan berperan penting dalam mempertahankan struktur jaringan sel (Rasyid, 2010). Alginat dimanfaatkan sebagai bahan aditif pada industri makanan, farmasi dan obat-obatan yang berfungsi sebagai pendispersi, pembentuk gel, thickening, stabilizing dan emulsifying agent (Pilnic et al., 1985; Toft et al., 1986).

\section{Metode}

\section{Bahan dan Alat}

Materi dalam penelitian ini adalah rumput laut jenis Padina sp. yang diambil dari perairan senggarang, Kota Tanjungpinang, Kepulauan Riau. Peta lokasi pengambilan bahan baku dapat dilihat pada Gambar 1. Penelitian dilaksanakan pada bulan Maret sampai dengan Mei 2017. 


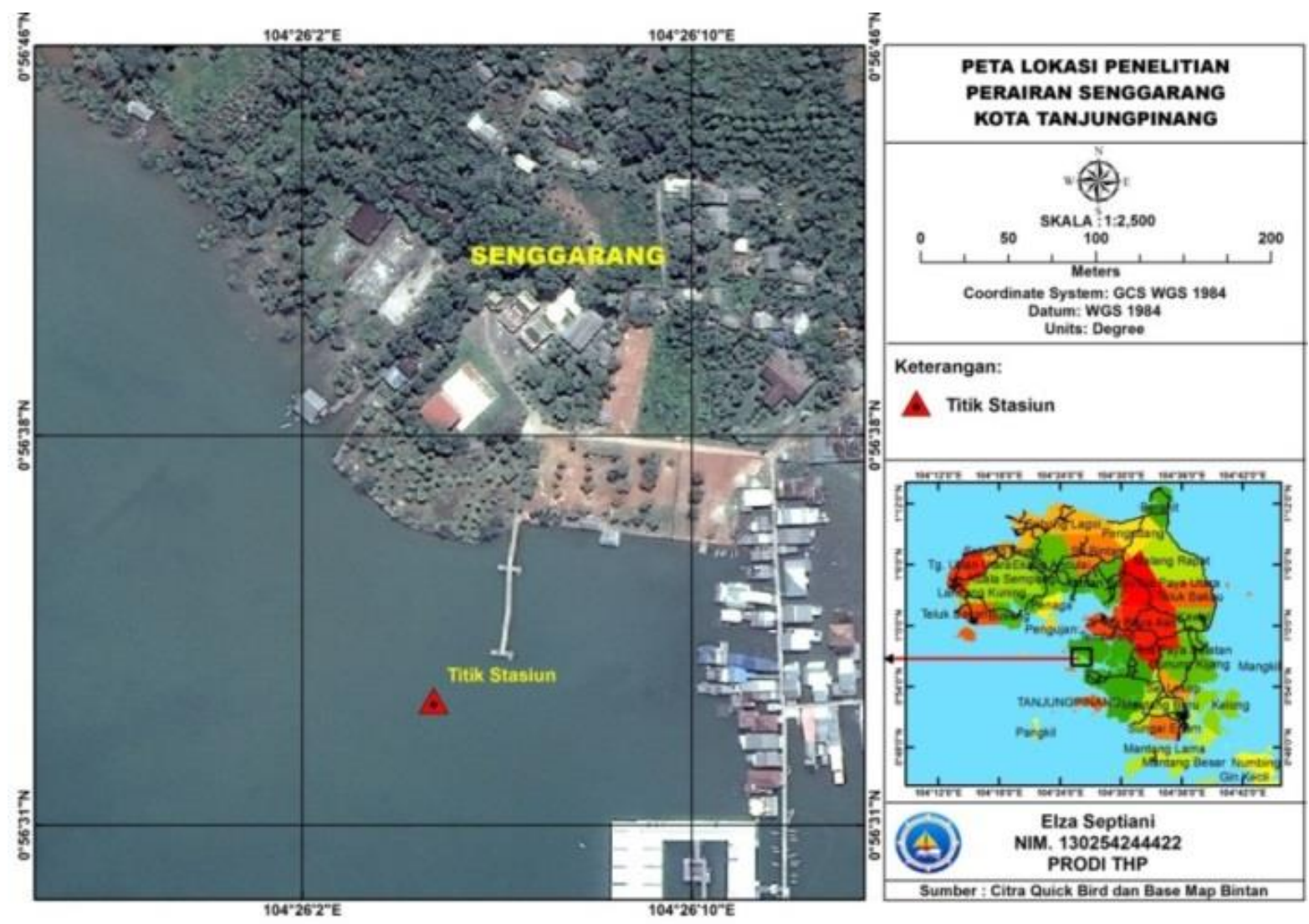

Gambar 1. Peta lokasi pengambilan bahan baku rumput laut cokelat Padi na sp.

Bahan yang digunakan dalam proses ekstraksi natrium alginat adalah $\mathrm{KOH}, \mathrm{HCl}$, $\mathrm{Na}_{2} \mathrm{CO}_{3}, \mathrm{CaO}, \mathrm{NaOH}$, dan etanol $96 \%$.

Alat yang digunakan untuk ekstraksi natrium alginat antara lain gelas beker, gelas piala, oven, timbangan digital, $\mathrm{pH}$ meter, kertas saring, dan blender. Alat yang digunakan untuk analisis sampel antara lain cawan pengabuan, tanur pengabuan, penjepit cawan, oven, desikator, Brookfield synchro-lecric viskometer, timbangan analitik, $\mathrm{pH}$ meter, dan aluminium foil.

\section{Ekstraksi Natrium Alginat}

Tahapan penelitian ini adalah modifikasi penelitian yang telah dilakukan oleh Yulianto (2007); Mirza et al., (2013); dan Wibowo et al., (2013). Adapun konsentrasi KOH yang digunakan dengan urutan sebagai berikut. Sampel kering sebanyak 50 gram dipotong dengan ukuran \pm 1 $\mathrm{cm}$. Sampel kemudian direndam dengan air tawar selama \pm 30 menit. Sampel kemudian direndam dengan larutan $\mathrm{KOH} 0,6 \%, 0,8 \%$ dan $1 \%$ selama 30 menit dengan perbandingan 1:20 dipanaskan dengan suhu $\pm 60 \stackrel{\circ}{\circ}$. Rumput laut yang telah direndam selanjutnya dicuci dengan air mengalir.

Sampel kemudian direndam $\mathrm{HCl} 5 \%$ dengan perbandingan 1:20 selama 1 Jam. Selanjutnya dicuci dengan air mengalir. Proses selanjutnya dilakukan penambahan larutan $\mathrm{Na}_{2} \mathrm{CO}_{3} \quad 7 \%$ dengan perbandingan 1:20 dipanaskan dengan suhu konstan $\pm 60{ }^{\circ} \mathrm{C}$ selama 2 jam. Hasil yang didapat kemudian disaring dan diperas dengan kain belacu sehingga menghasilkan ampas dan filtrat. Filtrat kemudian dimasukkan kedalam wadah dan ditambahkan $\mathrm{CaO} 13 \%$ dengan perbandingan 1:1. Sampel kemudian ditambahkan larutan $\mathrm{HCl} 5 \%$ dengan perbandingan 1:20 dengan tujuan untuk membentuk asam alginat. Asam alginat diendapkan dengan larutan $\mathrm{NaOH} 2 \%$ sampai $\mathrm{pH}$ netral. Natrium alginat yang dihasilkan ditambahkan dengan etanol $96 \%$ dengan perbandingan 1:5. Pengeringan dilakukan didalam oven dengan suhu $\pm 60{ }^{\circ} \mathrm{C}$ selama $\pm 24 \mathrm{Jam}$, kemudian ditepungkan. Natrium alginat yang terbentuk dianalisa kadar air (AOAC 2005), kadar abu (AOAC 2005), rendemen (AOAC 2005), viskositas (Cottrel dan Kovacs 1980), dan pH (AOAC 2005). Analisis data diuji secara statistik berdasarkan oneway ANOVA $(P<0,05)$ dan uji lanjut menggunakan Duncan.

\section{Analisis Fisiko-Kimia}

\section{Kadar air (AOAC, 2005)}

Cawan porselen dikeringkan dalam oven pada suhu $100 \pm 5^{\circ} \mathrm{C}$ selama 30 menit, kemudian didinginkan dalam desikator untuk menjaga kelembaban relatif $(\mathrm{RH})$ dan ditimbang beratnya. Selanjutnya ditambahkan $\pm 2 \mathrm{~g}$ sampel dalam 
cawan, ditimbang dan dikeringkan dalam oven selama 24 jam pada suhu $100 \pm 5{ }^{\circ} \mathrm{C}$. Sampel yang telah dioven kemudian ditempatkan pada desikator untuk menjaga kelembaban relatif $(\mathrm{RH})$ setelah dipanaskan. Perlakuan ini diulangi sampai memperoleh bobot konstan. Perhitungan :

Kadar air $(\%)=\frac{\mathrm{B}-\mathrm{C}}{\mathrm{B}-\mathrm{A}} \times 100 \%$

Keterangan :

$A=$ Berat cawan kosong $(g)$

$\mathrm{B}=$ Berat cawan + sampel sebelum pengeringan $(\mathrm{g})$

$\mathrm{C}=$ Berat cawan + sampel sesudah pengeringan $(\mathrm{g})$

\section{Kadar Abu (AOAC, 2005)}

Cawan porselen dikeringkan dalam oven pada suhu $100 \pm 5{ }^{\circ} \mathrm{C}$ selama 30 menit kemudian didinginkan dalam desikator dan menimbang beratnya. Setelah itu memasukkan \pm $2 \mathrm{~g}$ sampel dalam cawan, kemudian dipijarkan dalam tanur dengan suhu $550-600{ }^{\circ} \mathrm{C}$ sampai pengabuan sempurna. Selanjutnya, sampel ditempatkan pada desikator. Perlakuan ini diulangi sampai memperoleh bobot konstan. Perhitungan :

Kadar abu $(\%)=\frac{\mathrm{C}-\mathrm{A}}{\mathrm{B}-\mathrm{A}} \times 100 \%$

Keterangan :

$A=$ Berat cawan kosong $(\mathrm{g})$

$\mathrm{B}$ = Berat cawan + sampel sebelum pengabuan (g)

$\mathrm{C}=$ Berat cawan + sampel sesudah pengabuan (g)

\section{Rendemen (AOAC, 2005)}

Rendemen merupakan perbandingan antara berat produk akhir dengan berat sampel kering. Rendeman dihitung dengan menggunakan rumus :

(\%) Rendemen $=\frac{\text { wa }}{w r} \times 100 \%$

Keterangan :

wa $=$ Berat produk akhir

$\mathrm{wr}=$ Berat sampel kering

\section{Viskositas (Cottrel dan kovacs, 1980)}

Sampel sebanyak $3 \mathrm{~g}$ dilarutkan dalam 250 $\mathrm{mL}$ akuades. Sampel tersebut dimasukkan ke dalam wadah dan diukur viskositasnya dengan menggunakan alat Brookfield viskometer pada suhu kamar dengan kecepatan 60 rpm. Angka yang dibaca dikalikan dengan 5 . Nilai viskositas dinyatakan dalam satuan centipoise $(C p)$.

\section{pH (derajat keasaman) (AOAC, 2005)}

Sampel natrium alginat ditimbang sebanyak $1 \mathrm{~g}$, kemudian dimasukkan dalam gelas ukur dan dilarutkan dengan $10 \mathrm{~mL}$ akuades. Sampel tersebut diukur keasamannya dengan $\mathrm{pH}$ meter.

\section{Analisis data (Steel dan Torie, 1991)}

Percobaan dilakukan menggunakan rancangan acak lengkap satu faktor, yaitu konsentrasi kalium hidroksida dengan 3 perlakuan $(0,6 \%$; $0,8 \%$; dan $1 \%)$ dan tiga kali ulangan. Model matematis rancangan tersebut adalah :

$Y i j=\mu+\alpha i+\varepsilon i j$

Keterangan :

$Y_{i j}=$ Nilai pengamatan dari perlakuan ke-i dan ulangan ke-j

$\mu=$ Pengaruh rata-rata umum

$\alpha i=$ Pengaruh perlakuan ke-i

zij = Pengaruh acak (galat percobaan pada konsentrasi tarf i ulangan ke-j

$=$ Ulangan dari setiap perlakuan 1,2,3

$=$ Perbedaan konsentrasi kalium hidroksida $(0,6 \% ; 0,8 \%$; dan $1 \%)$

\section{Hasil dan Pembahasan}

\section{Kadar Air}

Berdasarkan Tabel 1 dapat dilihat bahwa rata-rata persen kadar air berkisar 10,87-11,06\%. Histogram kadar air tersaji Gambar 2. Hasil penelitian yang diperoleh menunjukkan bahwa kadar air yang dihasilkan pada tiap perlakuan sudah memenuhi standar Food Chemical Codex (FCC) dimana kadar air natrium alginat $<15 \%$. Hasil yang diperoleh juga lebih baik dari pada penelitian sebelumnya yaitu Rasyid (2007) sebesar 11,93-12,28\%. Berdasarkan hasil uji statistik menunjukkan bahwa perlakuan perendaman rumput laut Padina sp. dalam larutan $\mathrm{KOH}$ yang berbeda tidak memberikan pengaruh yang tidak nyata terhadap natrium alginat yang dihasilkan (sig > 0,05). Penurunan kadar air alginat diakibatkan adanya suasana basa dari larutan $\mathrm{KOH}$ yang mampu menghambat terjadinya suatu peningkatan air dalam molekul alginat, dengan meningkatnya konsentrasi $\mathrm{KOH}$ yang digunakan maka dapat mengurangi garam-garam mineral yang terkandung didalamnya (Anwar et al., 2013).

\section{Kadar Abu}

Berdasarkan Tabel 1 dapat dilihat bahwa kadar abu natrium alginat yang dihasilkan berkisar antara 31,24-41,13\%. Histogram kadar abu tersaji Gambar 3. Hasil penelitian ini memiliki kadar abu yang tinggi dibandingkan standar Food Chemical 
Codex (FCC) dimana kadar abu natrium alginat $18-27 \%$ dan juga lebih tinggi dibandingkan dengan kadar abu yang dihasilkan penelitian sebelumnya Rasyid (2007) yaitu 28,2-29,07\%. Berdasarkan hasil uji statistik menunjukkan bahwa perlakuan perendaman rumput laut Padina sp. dalam larutan $\mathrm{KOH}$ yang berbeda memberikan pengaruh yang nyata terhadap natrium alginat yang dihasilkan $(s i g<0,05)$. Hasil uji lanjut Duncan diketahui bahwa terdapat perbedaan yang nyata antara perlakuan perendaman $\mathrm{KOH} \quad 0,8 \%$ dengan perlakuan perendaman $\mathrm{KOH} 0,6 \%$ dan $1 \%$. Namun, tidak ada perbedaan yang nyata antara perlakuan perendaman $\mathrm{KOH} 0,6 \%$ dan $1 \%$. Perendaman larutan $\mathrm{KOH}$ optimal terdapat pada konsentrasi $0,8 \%$. Hal ini karena, perlakuan $\mathrm{KOH} 0,8 \%$ mampu menarik zat anorganik yang terkandung pada rumput laut. Tingginya kadar abu pada hasil penelitian diduga berasal dari penggunaan $\mathrm{HCl}$ yang belum optimal sesuai dengan pernyataan Mirza et al., (2013) bahwa penggunaan $\mathrm{HCl}$ bertujuan untuk menghilangkan kotoran-kotoran epifit yang menempel dan melarutkan garamgaram alkali tanah. Truss et al., (2001) juga menambahkan, bahwa Padina sp. mempunyai fisik lebih lembut dan tipis, lebih mudah hancur pada saat ekstraksi. Kondisi ini dapat mengakibatkan semakin sulitnya proses pemisahan dan pemurnian antara alginat dengan kotoran-kotoran yang ada dalam larutan alginat termasuk mineral anorganiknya, sehingga dimungkinkan masih banyaknya kotoran-kotoran yang terbawa dalam larutan alginat.

Tabel 1. Hasil analisis natrium alginat rumput laut Padina sp. pada konsentrasi $\mathrm{KOH}$ yang berbeda

\begin{tabular}{|c|c|c|c|c|c|}
\hline \multirow{2}{*}{ Parameter } & \multicolumn{3}{|c|}{ Hasil Analisis } & \multirow{2}{*}{$\begin{array}{c}\text { Standar } \\
\text { Mutu }\end{array}$} & \multirow{2}{*}{ Padina australis } \\
\hline & $\mathrm{KOH} 0,6(\%)$ & $\mathrm{KOH} 0,8(\%)$ & $\mathrm{KOH} 1(\%)$ & & \\
\hline Kadar air (\%) & $10,93 \pm 0,87$ & $10,87 \pm 0,54$ & $11,06 \pm 0,85$ & $<15^{\mathrm{a}}$ & $11,93-12,28^{\mathrm{d}}$ \\
\hline Kadar abu (\%) & $40,28 \pm 4,29$ & $31,24 \pm 0,24$ & $41,13 \pm 1,97$ & $18-27^{\mathrm{a}}$ & $28,2-29,07^{d}$ \\
\hline Rendemen (\%) & $15,57 \pm 0,005$ & $17,82 \pm 0,005$ & $17,05 \pm 0,007$ & $>18^{\mathrm{b}}$ & $4,79-8,32^{d}$ \\
\hline Viskositas (cP) & $58,00 \pm 1,30$ & $55,10 \pm 1,01$ & $59,80 \pm 1,01$ & $10-5000^{c}$ & $37-125^{d}$ \\
\hline $\mathrm{pH}$ & $8,17 \pm 0,16$ & $8,21 \pm 0,51$ & $8,39 \pm 0,06$ & $3,5-10^{c}$ & \\
\hline
\end{tabular}

\footnotetext{
Sumber : ${ }^{\mathrm{a}}$ Food Chemical Codex 1981

${ }^{b}$ Winarno 1996

${ }^{c}$ McNeely dan Pettitt 1973

${ }^{\mathrm{d}}$ Rasyid 2007
}

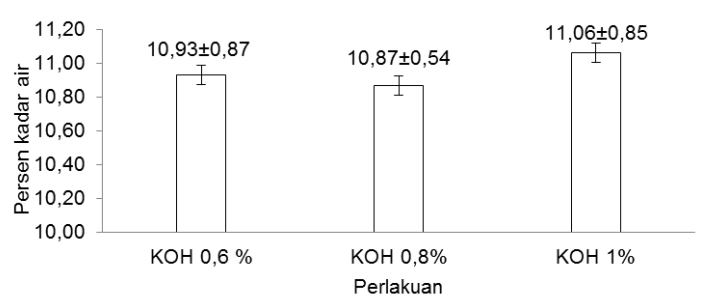

Gambar 2. Histogram kadar air (\%) natrium alginat rumput laut Padina sp. pada konsentrasi $\mathrm{KOH}$ yang berbeda

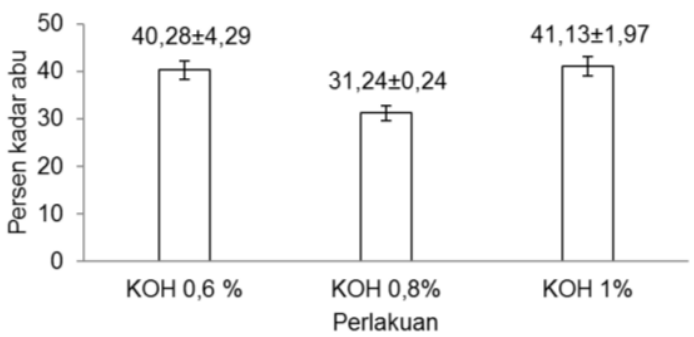

Gambar 3. Histogram kadar abu (\%) natrium alginat rumput laut Padina sp. pada konsentrasi $\mathrm{KOH}$ yang berbeda

\section{Rendemen}

Berdasarkan Tabel 1 dapat dilihat bahwa rata-rata rendemen berkisar 15,57-17,82\%. Histogram rendemen tersaji Gambar 4. Hasil penelitian yang diperoleh, menunjukkan bahwa rendemen yang dihasilkan lebih rendah dibandingkan rendemen yang ditetapkan oleh Winarno (1990) yaitu $>18 \%$ namun lebih tinggi dibandingkan dengan rendemen yang dihasilkan oleh penelitian sebelumnya Rasyid (2007) yaitu 4,79-8,32\%. Berdasarkan hasil uji statistik menunjukkan bahwa perlakuan perendaman rumput laut Padina sp. dalam larutan $\mathrm{KOH}$ memberikan pengaruh nyata terhadap natrium alginat yang dihasilkan $(\mathrm{sig}<0,05)$.

Hasil uji lanjut Duncan diketahui bahwa terdapat perbedaan yang nyata antara masingmasing perlakuan. Rendemen natrium alginat yang tertinggi terdapat pada perlakuan $\mathrm{KOH}$ $0,8 \%$. Hal ini diduga bahwa, perlakuan $\mathrm{KOH} 0,8 \%$ mampu menarik garam-garam mineral, kotorankotoran, selulosa dan zat-zat organik yang terkandung pada rumput laut Padina sp. Budiyanto dan Djazuli (1997) menjelaskan tinggi dan rendah rendemen rumput laut dipengaruhi 
oleh habitat (intensitas cahaya, besar kecilnya ombak/arus, nutrisi perairan dan lain-lain).

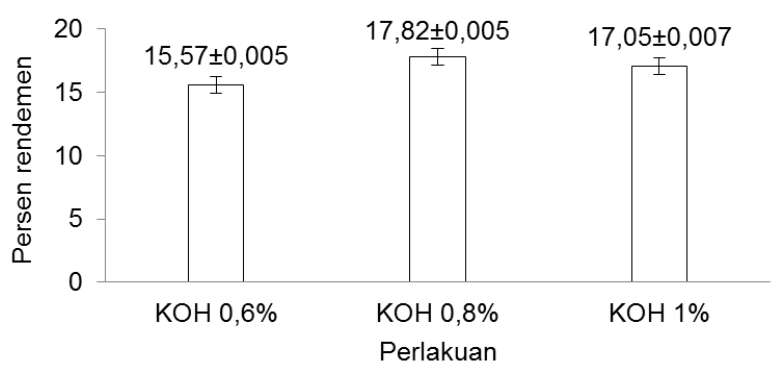

Gambar 4. Histogram rendemen (\%) natrium alginat rumput laut Padina $\mathrm{sp}$. pada konsentrasi $\mathrm{KOH}$ yang berbeda

\section{Viskositas}

Berdasarkan Tabel 1 dapat dilihat bahwa rata-rata viskositas sebesar 275,50-299,00 cP. Histogram viskositas tersaji Gambar 5. Hasil penelitian yang diperoleh, menunjukkan bahwa viskositas yang dihasilkan sudah memenuhi standar Food Chemical Codex (FCC) dimana viskositas natrium alginat berkisar 10-5000 cP dan termasuk kedalam tingkatan natrium alginat kekentalan tinggi 110-800 cP (King, 1982). Hasil penelitian ini lebih baik dibandingkan dengan penelitian sebelumnya Rasyid (2007) nilai viskositasnya berkisar 37-125 cP. Berdasarkan hasil uji statistik menunjukkan bahwa perlakuan perendaman rumput laut $P$ adina sp. dalam larutan $\mathrm{KOH}$ memberikan pengaruh nyata terhadap natrium alginat yang dihasilkan $(\mathrm{sig}<0,05)$. Perlakuan $\mathrm{KOH} \quad 0,8 \%$ menghasilkan kadar viskositas yang paling rendah karena natrium alginat yang diekstrak pada perlakuan ini mengandung rantai polimer yang berbobot molekul rendah sesuai dengan kondisi $\mathrm{pH}$ yang bernilai basa. Eriningsih et al., (2014) menyatakan alginat dapat dikarakterisasi dari derajat viskositasnya dalam bentuk larutan. Viskositas alginat dipengaruhi oleh kekuatan gel, konsentrasi alginat, derajat polimerisasi dan berat molekulnya. Viskositas alginat juga dipengaruhi oleh suhu, kondisi asam dan perbandingan unit $\mathrm{M}$ dan $\mathrm{G}$ dari molekul alginat. Peningkatan viskositas tergantung pada adanya asam guluronat dan asam manuronat yang tinggi (Amir et al., 2012). Peningkatan proporsi unit $\mathrm{G}$ menghasilkan bahan lebih kental. Perbandingan $M$ dan $G$ mempengaruhi laju pembentukan hidrogel dan/atau karakteristik akhir dari hidrogel. Alginat yang mengandung asam guluronat yang tinggi cenderung mempunyai struktur yang kaku (rigid) serta mempunyai porositas yang besar, sedangkan yang mengandung asam manuronat yang tinggi mempunyai struktur yang tidak kaku dan lebih fleksibel (Mandal et al., 2010).

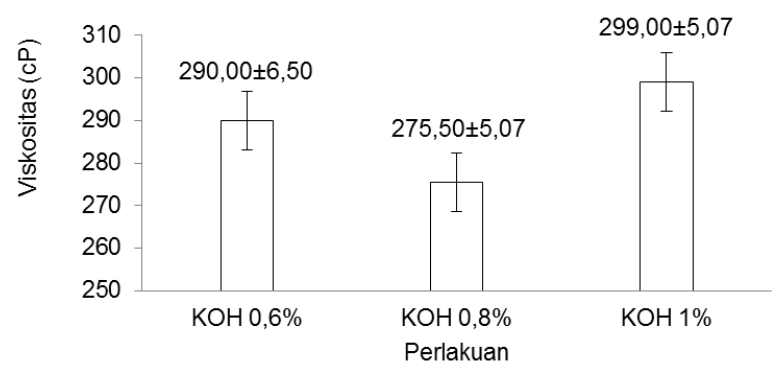

Gambar 5. Histogram viskositas (cP) natrium alginat rumput laut Padina $\mathrm{sp}$. pada konsentrasi $\mathrm{KOH}$ yang berbeda

pH

Berdasarkan Tabel 1 dapat dilihat bahwa rata-rata $\mathrm{pH}$ sebesar 8,17-8,39. Histogram $\mathrm{pH}$ tersaji Gambar 6. $\mathrm{pH}$ tertinggi diperoleh dari perlakuan $\mathrm{KOH} 1 \%$ yaitu 8,39 sedangkan $\mathrm{pH}$ terendah diperoleh dari perlakuan $\mathrm{KOH} 0,6 \%$. Hal ini diduga semakin tinggi konsentrasi perendaman dengan larutan $\mathrm{KOH}$, maka nilai $\mathrm{pH}$ yang dihasilkan juga semakin tinggi. Hasil penelitian yang diperoleh, menunjukkan bahwa $\mathrm{pH}$ yang dihasilkan sudah memenuhi standar Food Chemical Codex (FCC) dimana pH natrium alginat berkisar 3,5-10. Oleh karena itu, $\mathrm{pH}$ natrium alginat yang dihasilkan pada penelitian ini dapat digunakan untuk pangan maupun non pangan. Berdasarkan hasil uji statistik menunjukkan bahwa perlakuan perendaman rumput laut Padina $\mathrm{sp}$. dalam larutan $\mathrm{KOH}$ tidak memberikan pengaruh yang nyata terhadap natrium alginat yang dihasilkan. Tingkat $\mathrm{pH}$ mempengaruhi perbedaan larutan alginat, tergantung dari tipe alginat yang digunakan. Larutan $\mathrm{Na}$-alginat tidak stabil di atas $\mathrm{pH} 10$ dan terjadi endapan $\mathrm{Na}$ alginat pada $\mathrm{pH}$ kurang dari 3,5 (Nussinovitch, 1997).

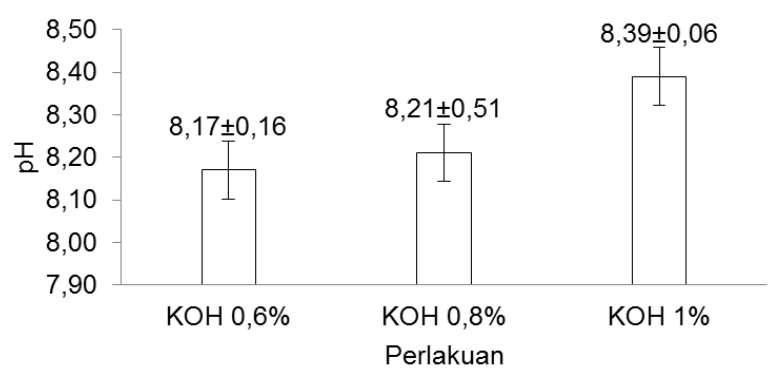

Gambar 6. Histogram pH natrium alginat rumput laut Padina sp. pada konsentrasi $\mathrm{KOH}$ yang berbeda

\section{Simpulan}

Berdasarkan hasil penelitian yang telah dilakukan dapat disimpulkan bahwa perlakuan 
perendaman dengan menggunakan konsentrasi $\mathrm{KOH}$ yang berbeda memberikan pengaruh terhadap kualitas kadar abu dan viskositas natrium alginat yang dihasilkan. Hasil perlakuan terbaik terdapat pada konsentrasi $\mathrm{KOH} \mathrm{0,8 \%} \mathrm{yaitu}$ dengan nilai kadar air 10,87\%, kadar abu 31,24\%, rendemen $17,82 \%$, viskositas $275,50 \mathrm{cP}$ dan $\mathrm{pH}$ 8,21 .

Saran yang dapat diberikan dari hasil penelitian ini adalah perlu dilakukan penelitian lebih lanjut untuk mendapatkan natrium alginat dari rumput laut Padina sp. yang memiliki kadar abu yang sesuai standar mutu produk dengan penggunaan konsentrasi $\mathrm{HCl}$ yang tepat. Selain itu, perlu mempelajari pembuatan natrium alginat

\section{Daftar Refernsi}

Amir, H., Subaryono, Pranoto, Y., Tazwir, Ustadi., 2012. Pengembangan Metode Ekstraksi Alginat dari Rumput Laut Sargassum sp. sebagai Bahan Pengental. Agritech. 32(1): 1-8.

Anwar Fauzi, Djunaedi Ali, Gunawan Widi Santosa., 2013. Pengaruh Konsentrasi $\mathrm{KOH}$ yang Berbeda Terhadap Kualitas Alginat Rumput Laut Coklat Sargassum duplicatum J. G. Agardh. Journal Of Marine Research. 2(1):7-14.

[AOAC] Association of Official Analitycal Chemists., 2005. Official Methods of Analysis of The Association of Official Analytical Chemist. 18th ed, Gaithersburg: USA.

Budiyanto, Djazuli., 1997. Teknologi pengolahan alginat dari beberapa jenis rumput laut marga sargassum sp. Jurnal Pascapanen Perikanan. 5(1):12-16.

Cottrell, I,W., Kovacs, P., 1980. Alginates Dalam Davidson RL. (Eds.). Hand Book of Water Soluble Gums and Resin. McGraw-Hill Book Co. New York 2 : 2 43.

Eriningsih,R., Marlina R., Mutia T., Sana A,W., Titis A., 2014. Eksplorasi kandungan pigmen dan alginat dari rumput laut coklat untuk proses pewarnaan kain sutera. Jurnal Arena Tekstil. 29(2):73-80.

Food Chemical Codex., 1981. Food Chemical Codex. Washington: National Academy Press.

Junianto., 2006. Rendemen dan Kualitas Algin Hasil Ekstraksi Alga (Sargassum sp.) dari Pantai Selatan Daerah Cidaun Barat, Jurnal Bionatura, 8(2):152-168. dari rumput laut jenis lainnya untuk membandingkan kualitas natrium alginat.

\section{Ucapan Terimakasih}

Penulis menyampaikan terimakasih kepada R. Marwita Sari Putri dan Ginanjar Pratama yang telah membimbing dan mengarahkan, Laboratorium Fakultas ilmu kelautan dan Perikanan Universitas Maritim Raja Ali Haji Tanjungpinang, Laboratorium Pembinaan dan Pengujian Mutu Hasil Perikanan (LPPMHP) Provinsi Kepulauan Riau, laboratorium Institut Pertanian Bogor yang telah memberikan bantuan dan fasilitas dalam penulisan jurnal ilmiah ini.

Kadi, A., 2005. Kesesuaian Perairan Teluk Klabat Pulau Bangka Untuk Usaha Budidaya Rumput Laut, Jurnal Perikanan. 7(1):65-70.

Kendall, W.F., Darrabie M.D., El-Shewy H.M., Opara E.C. 2004. Effect of Alginate Composition and Purity on Alginate Microspheres, Journal Microencapsul, 21(8):821-8.

King, AH., 1982. Brown Seaweed Extract (Alginat). Di dalam: Glicksman M, editor. Food Hydrocolloids, Vol II, CRC Press Inc: Florida.

[KKP] Kementerian Kelautan dan Perikanan. 2015. Komoditas Rumput Laut Kian Strategis. Nomor 025/PDSI/HM.420/IV/2015. Siaran Pers.

Mandal, S., Kumar, S.S., Krishnamoorthy, B., Basu, S.K., 2010. Development and Evaluation of Calcium Alginate Beads Prepared by Sequential and Simultaneous Methods, Brazilian Journal of Pharmaceutical Sciences, 46(4).

Mirza, M., Ali, R., Rini, P., 2013. Pengaruh Perendaman Larutan $\mathrm{KOH}$ dan $\mathrm{NaOH}$ Terhadap Kualitas Alginat Rumput Laut Sargassum polycystum C.A. Agardh, Jurnal Penelitian Kelautan, 2(1):41-47.

Mushollaeni, W. dan E. Rusdiana., 2011, Karakterisasi Natrium Alginat Dari Sargassum sp., Turbinaria sp., Dan Padina sp., J. Teknol. Dan Industri Pangan, 22 (1).

Nussinovitch, A. 1997. Hydrocolloid Applications, Gum Technology in Food and Other Industries. Blackie Academic Press \& Professional: London.

Rasyid, A., 2007. Ekstraksi natrium alginat dari Padina australis, Oseanologi dan Limnologi di Indonesia, 33(2):271-279. 
Rasyid, A., 2010. Ekstraksi Natrium Alginat Dari Alga Coklat Sargassum echinocarphum, Oseanologi dan Limnologi di Indonesia, $36(3): 393-400$.

Subaryono., Apriani, S. N., 2010. Pengaruh Dekantasi Filtrat Pada Proses Ekstraksi Alginat Dari Sargassum sp Terhadap Mutu Produk Yang Dihasilkan. Jurnal Pascapanen dan Bioteknologi Kelautan dan Perikanan. 5(2):165-174.

Toft, K., Grasdalen, H., Smidsrod O., 1986. Synergistic Geletion of Alginates and Pectins. ACS Symposium Series, 310: 117132.

Truss, Vaher, Taure., 2001. Algal Biomass from Fucus vesiculosus (Phaeophyta): Investigation of the Mineral and Alginate Components. Proc Estonian Acad Sci Chem.50(2):95-103.

Wibowo, A., Ridlo, A., Sedjati, S., 2013. Pengaruh suhu ekstraksi terhadap kualitas alginat rumput laut turbinaria sp. dari pantai krakal, gunung kidul-yogyakarta, Jurnal Penelitian Kelautan. 2(3):15-24.

Winarno, F.G., 1990. Teknologi Pengolahan Rumput Laut. Jakarta: Pustaka Sinar Harapan.

Yulianto, K., 2007. Pengaruh konsentrasi natrium hidroksida terhadap viskositas na-alginat dari sargassum duplicatum j.g. agardh (phaeophyta). Pusat Penelitian Oseanografi dan Limnologi-LIPI, Jurnal Nasional. 33(2):295-306.

Pilnic, W., and Rombouts, F., 1985. Polysaccharides and Food Processing, Carbohydr. Res, 142:93-105.

Viswanathan, S. and Nallamuthu, T., 2014. Extraction of Sodium Alginate from Selected Seaweeds and Their Physiochemical and Biochemical Properties, International Journal of Innovative Research in Science, Engineering and Technology, 3(4). 